\title{
Behavioral Counseling of Theory of Planned Behavior-Based to Increase Sufferers' Intention in Preventing Recurrent Ischemic Stroke: A Randomized Control Trial
}

\author{
Novian Mahayu Adiutama', \\ Hera Hijriani $^{2}$, Aat Agustini $^{2}$, \\ Wardah Fauziah ${ }^{1}$, Nurizzi \\ Rifqi Ferdian ${ }^{1}$, Bayu \\ Nirwana $^{1}$, Agusta Dian Ellina ${ }^{3}$ \\ ${ }^{1}$ Program Studi Keperawatan, \\ Jurusan Agroindustri, \\ Politeknik Negeri Subang \\ ${ }^{2}$ Program Studi S1 \\ Keperawatan, STIKes YPIB \\ Majalengka \\ ${ }^{3}$ Pendidikan Profesi Ners, \\ Fakultas Keperawatan dan \\ Kebidanan, Institut Ilmu \\ Kesehatan STRADA Indonesia \\ Email: \\ adiutamanovian@gmail.com
}

Received : October $4^{\text {nd }} 2021$

Accepted : October $15^{\text {rd }} 2021$

Published : November $27^{\text {th }} 2021$

\begin{abstract}
Introduction: Ischemic stroke has become the leading cause of premature death in the last two decades. The biggest problem in preventing recurrence ischemic stroke is the compliance of the sufferers and the obedient behavior will arise only if they are consistent and have a strong intention. This study aims to determine the effect of behavioral counseling in increasing the intention to prevent recurrent ischemic stroke by using the theory of planned behavior model approach. Methods: Randomized Control Trial was conducted on 64 patients after an ischemic stroke that was managed by a public health center in East Java, Indonesia. Simple random sampling technique was used to take samples in this study. We provided behavioral counseling regarding the prevention of ischemic stroke recurrence to the treatment group using the Behavioral module which was compiled based on the guidelines from the Theory of Planned Behavior (TPB), while the intention variable was measured using the intention measurement instrument from the TPB Questionaries. The data obtained were then analyzed by using an independent $t$ test. Results: The result revealed that there was a significant difference in the mean value of the intention variable between the control group and the treatment group after the TPB-based behavioral counseling intervention for 1 month ( $p=0.015$ ). Discussion: The behavioral counseling of TPB-based can be implemented as an alternative way in increasing the sufferers' intention to prevent recurrence ischemic stroke. Further research in a broader scope is needed to prove the effectiveness of behavioral counseling on the structural values of the Theory of Planned Behavior.
\end{abstract}

Keywords: Intention, ischemic stroke, theory of planned behavior

Copyright $@ 2021$ IIK STRADA Indonesia All right reserved.

This is an open-acces article distributed under the terms of the Creative Commons Attribution-ShareAlike 4.0 International License.

\section{INTRODUCTION}

Ischemic stroke has become a leading cause of premature death in the last two decades (Caprio \& Sorond, 2018). Farrag et al. (2017) emphasized that the biggest problem in preventing recurrence ischemic stroke is the compliance of the sufferers and the obedient behavior will arise only if they are consistent and have a strong intention. Generally, the stronger the intention to engage in a behavior, the more likely it is to do so (Adiutama et al., 2018a). The global scale mentioned that stroke is the second leading cause of death and disability in the world, either due to the first or second 
stroke (American Heart Association, 2015). The risk of suferers' recurrence after 30 days from the first stoke is $3 \%-10 \%$, after 1 year after the first stroke $5 \%-14 \%$ and after 5 years from the first stoke is $25 \%-40 \%$ (NSA, 2012).

A statistical study shows that 1 in 8 people who experience a stroke dies within the first 30 days, and 1 in 4 people who have a stroke die within one year (Folyovich et al., 2018). Indonesia is the country with the largest number of stroke sufferers in Asia (Ministry of Health, 2018). East Java Province ranks the 4 th highest prevalence of stroke in Indonesia with 16 per mile population (Ministry of Health, 2018).

The recurrence strokes are believed to cause worse conditions for sufferers (Hu et al., 2017). Those who experienced recurrence strokes are more at risk of experiencing a decrease in the level of ability of daily activities compared to other sufferers with a first stroke (Venketasubramanian et al., 2017). The patients with recurrence strokes are also at risk for cognitive impairment (Wilson \& Ashcraft, 2018). Cognitive impairment in recurrence stroke is considered more severe than the first stroke (Wilson \& Ashcraft, 2018). The impact of recurrent strokes can be prevented by providing counseling on how to prevent recurrent strokes (Jones et al., 2010). The previous research conducted by Modi et al. (2018) showed that health promotion with behavioral counseling was able to increase the desired behavior to be displayed and persisted in the future. Behavioral counseling can influence the dimensions of intensity or intention. According to the Theory of Planned Behavior (TPB), intentions are formed from 3 dimensions, namely: 1) attitude towards behavior as a person's desire to behave because he knows the positive impact of the behavior 2) subjective norm as a person's desire to perform behavior because of a support from a closest friend, family, or other people around him 3 ) perceived behavioral control as a person's perception of obstacles or a support in carrying out a certain behavior (Ajzen, 2005).

Based on the facts and data described above, we conducted RCT study with the aim to analyze the effect of behavioral counseling in increasing the sufferers' intention of recurrence ischemic stroke by using the theory of planned behavior approach.

\section{MATERIALS AND METHODS}

A Randomized Control Trial (RCT) was conducted on 64 patients after an ischemic stroke that was managed by a public health center in East Java, Indonesia. This study was conducted in September 2021. The independent variables in this study were "behavioral counseling of TPB-based", and "intention to prevent recurrent ischemic stroke" as the dependent variable. The sample was taken by using a simple random sampling technique and divided into 2 groups, 32 respondents in the treatment group and 32 respondents in the control group.

The instrument used as a behavioral counseling guide is a module entitled "Behavioral Face to Face Nursing Education Module" (Adiutama et al., 2018b), in which the researcher obtained permission from the author to use this module for research purposes. This counseling is carried out using the lecture method through face-to-face home visits. Educational materials are prepared by referring to the 3 main factors that form intentions from the Theory Planned of Behavior. Home visits were carried out 4 times in four weeks. 1) The first meeting material is the benefits and importance of adherence to prevent recurrence which includes routine control, blood pressure control, weight control, nutritional compliance, physical activity regulation, and not smoking, as well as an overview to the client about the risk of recurrence due to non-compliance; 2) The second meeting material is about how to have a positive attitude towards treatment by building confidence; 3 ) The third meeting material is addressed to patients and families about subjective norms and motivations from families to prevent recurrence; 4) The material for the fourth meeting is about how to get rid of inhibiting perceptions and build perceptions that support relapse prevention. Moreover, the dependent variable measurement instrument used an Intention questionnaire which was modified from the TPB Questionnaire. The researcher modified the form of the questions and also the content of the questions to suit the research theme. This intention measurement questionnaire consists of 10 question items. The range of scores for each question is 1 to 7 (Semantics Differential Scale). Respondents were asked to mark $(\sqrt{ })$ on the appropriate scale. The sum of the scores for each answer will be the dependent variable score (12-84).

Independent t-test was used to analyze the difference in the value of "Intention to Prevent Recurrence Ischemic Stroke" between the treatment group and the control group, the significance 
level used was $(\mathrm{p}<0.05)$. To ensure the equality of respondents, we conducted a homogeneity test using the Levene-test. Additionally, Kolmogorov-Smirnov was used to test the normality of the data collected. This study protocol has been approved by the Indonesian Commission of Health Research Ethics.

\section{RESULTS}

Table 1 showed that the characteristics of respondents (clients) in the control and treatment groups have homogeneous data ( $p>0.05)$, both age, gender, education, occupation, and marital status. The most age ranged from 56 to 65 years (50\% in the treatment group and $65.6 \%$ in the control group). Most of the sexes were male (53.1\% in the treatment group and 65.6\% in the control group). The highest educational status in the treatment and control groups was high school $(43.8 \%$ in the treatment group and $43.8 \%$ in the control group. The most types of work in the treatment and control groups were private, each with $34.3 \%$ and $46.9 \%$ Most of the respondents in this study had married marital status, $53.2 \%$ in the treatment group and $50 \%$ in the control group.

Table 1. Socio-demographic Characteristics $(n=64)$

\begin{tabular}{|c|c|c|c|c|c|c|}
\hline \multirow{2}{*}{ No } & \multirow{2}{*}{ Socio-demographic } & \multicolumn{2}{|c|}{ Treatment Group $(n=32)$} & \multicolumn{2}{|c|}{ Control Group $(n=32)$} & \multirow{2}{*}{ Homogeneity } \\
\hline & & $\mathbf{n}$ & $\%$ & $\mathbf{n}$ & $\%$ & \\
\hline 1 & Age & & & & & 0,654 \\
\hline & $46-55 \mathrm{YO}$ & 14 & 43,8 & 10 & 31,3 & \\
\hline & $56-65 \mathrm{YO}$ & 16 & 50 & 21 & 65,6 & \\
\hline & $>65 \mathrm{YO}$ & 2 & 6,2 & 1 & 3,1 & \\
\hline & Total & 32 & 100 & 32 & 100 & \\
\hline 2 & Sex & & & & & 0,309 \\
\hline & Male & 17 & 53,1 & 21 & 65,6 & \\
\hline & Female & 15 & 46,9 & 11 & 34,4 & \\
\hline & Total & 32 & 100 & 32 & 100 & \\
\hline 3 & Education & & & & & 0,922 \\
\hline & Primary & 6 & 18,8 & 8 & 25 & \\
\hline & Secondary & 11 & 34,4 & 9 & 281 & \\
\hline & High School & 14 & 43,8 & 14 & 43,8 & \\
\hline & Bachelor & 1 & 3,1 & 1 & 3,1 & \\
\hline & Total & 32 & 100 & 32 & 100 & \\
\hline 4 & Jobs & & & & & 0,771 \\
\hline & Tidak Bekerja & 9 & 28,1 & 8 & 25 & \\
\hline & Private & 11 & 34,4 & 15 & 46,9 & \\
\hline & Entrepreneur & 9 & 28,1 & 7 & 21,9 & \\
\hline & Civil Servant & 3 & 9,4 & 2 & 6,2 & \\
\hline & Total & 32 & 100 & 32 & 100 & \\
\hline 5 & Marital Status & & & & & 0,802 \\
\hline & Married & 17 & 53,1 & 16 & 50 & \\
\hline & Not Married & 15 & 46,9 & 16 & 50 & \\
\hline & Total & 32 & 100 & 32 & 100 & \\
\hline
\end{tabular}

Table 2. Normality and Homogeneity $(n=64)$

\begin{tabular}{|c|c|c|c|c|c|c|}
\hline \multirow{3}{*}{ Variable } & \multicolumn{4}{|c|}{ Group } & \multirow{3}{*}{ Homogenitas } & \multirow{3}{*}{ Normalitas } \\
\hline & \multicolumn{2}{|c|}{ Treatment $(n=32)$} & \multicolumn{2}{|c|}{ Control $(n=32)$} & & \\
\hline & Mean & SD & Mean & SD & & \\
\hline $\begin{array}{l}\text { Intention to prevent recurrent } \\
\text { ischemic stroke }\end{array}$ & 61,22 & 19,57 & 62,06 & 21,55 & 0,703 & 0,314 \\
\hline
\end{tabular}


Table 2 showed that the data regarding the intention to prevent recurrent strokes obtained in this study are homogeneous, while based on the normality test using Kolmogorov Smirnov, it shows that the data obtained in this study have a normal distribution. Therefore, the data obtained in this study have met the requirements to be analyzed using parametric tests.

Table 3. Pre-test and Post-test. ( $\mathrm{n}=64)$

\begin{tabular}{llllll}
\hline & \multicolumn{3}{c}{ Intention to prevent recurrent ischemic stroke } & \multirow{2}{*}{ p-value } \\
\cline { 2 - 5 } & \multicolumn{3}{c}{ Pre test } & \multicolumn{3}{c}{ Post test } & \\
\cline { 2 - 5 } & Mean & $S D$ & Mean & SD & \\
\hline Treatment group $(\mathrm{n}=32)$ & 61,22 & 19,57 & 69,36 & 17,87 & 0,012 \\
Control Group $(\mathrm{n}=32)$ & 62,06 & 21,55 & 63,33 & 13,53 & 0,518 \\
\hline
\end{tabular}

The different test of pre and post test data in each group was carried out using paired t-test. The results of the different test showed that there was a significant difference between the values before and before the counseling behavior intervention in the treatment group $(p=0.012)$, while in the control group there was no significant difference $(\mathrm{p}=0.518)$.

Table 4. Test result of delta value $(n=64)$

\begin{tabular}{|c|c|c|c|c|c|}
\hline \multirow{3}{*}{ Variable } & \multicolumn{4}{|c|}{ Delta Value } & \multirow{3}{*}{ p-value } \\
\hline & \multicolumn{2}{|c|}{ Treatment $(\mathrm{n}=32)$} & \multicolumn{2}{|c|}{ Control $(n=32)$} & \\
\hline & Mean & SD & Mean & $\mathrm{SD}$ & \\
\hline $\begin{array}{l}\text { Intention to prevent recurrent ischemic } \\
\text { stroke }\end{array}$ & 8,25 & 19,57 & 1,76 & 21,55 & 0,031 \\
\hline
\end{tabular}

Table 4 shows that there is a significant difference in delta values between the two groups $(p<0.031)$. This means that behavioral counseling of the Theory of Planned Behavior-based significantly influences the intention to prevent recurrent ischemic stroke.

\section{DISCUSSION}

Intention in this study is defined as the desire or intention in the respondent's heart to prevent recurrent ischemic stroke. Statistically, behavioral counseling of the Theory of Planned Behaviorbased has proven to influence post-stroke patients' intention to prevent recurrence. The results of the paired $t$ test showed that there was a significant difference between the mean intention value before and after behavioral counseling intervention of Theory of Planned Behavior-based $(p=0.012)$, while the control group did not find this difference (0.518). After the sufferers are given behavioral counseling of the Theory of Planned Behavior-based, their intention to prevent recurrent ischemic strokes tends to experience a significant increase. This significant improvement can be achieved through regular interactions by using behavioral counseling which is carried out face to face 4 times to patients and families.

The results of this study are matched with a study conducted at the University of Pennsylvania Hospital which reported that education based on behavioral beliefs and reminder messages proved effective in maintaining the intention to take doses (Reese et al., 2016). Previous studies on intention in the Theory of Planned Behavior explained that intention and behavior in the Theory of Planned Behavior-based are able to explain a person's intention and obedient behavior in a treatment (Adiutama et al., 2021). Adherence to treatment also depends on the individual's own personal orientation. The cognitive education model moderated by the Theory of Planned Behavior-based has 
confirmed to be effective in understanding a person's health intentions and behavior (Peleg et al., 2017).

Behavior has the basis of a belief approach that forms intentions and encourages individuals to perform a certain behavior, the main factors forming intentions are attitude, subjective norm, perceived behavior control (Adiutama \& Fauzi, 2020). The educational intervention of the Theory of Planned Behavior-based in this study provides an overview of post-ischemic stroke patients on how to form positive attitudes, subjective norms, and perceived behavior control, so that the subjects can generate strong intentions to prevent recurrent strokes. Behavioral counseling of the Theory of Planned Behavior-based which was carried out face to face 4 times in this study played a role in maintaining the stability of intentions that had been formed previously.

Intention is an indication of how strong the individual's belief is to try a behavior, and how much effort to behave. A person's factor to behave is influenced by the desire, intentional, or because it has been planned. Behavioral intention is a plan or desire, and in this case, the intention cannot be said to be a behavior (Miller et al., 2015). The intention to behave to prevent stroke recurrence is the desire of someone who is planned to do the prevention (Farrag et al., 2017). A person's intention is great because of the strong individual's belief to try the behavior, the support from the closest people and the person's perception showed that the behavior can be done. On the other hand, a person will have low intentions because the person does not have the confidence to try the behavior, there is no support from the closest person and the person's perception that the behavior will not be able to be carried out. In addition, after the respondents are given counseling, finally they have a strong belief so that the intention to prevent stroke recurrence increases as well.

\section{CONCLUSION}

Based on the discussion above, it can be concluded that behavioral counseling of the Theory of Planned Behavior-based can increase the intention of post-stroke patients in preventing recurrent ischemic stroke. Behavioral counseling of the Theory of Planned Behavior-based was carried out by using a module guide which was compiled based on the guideline of the theory of planned behavior model. However, the accuracy of intentions in predicting behavior is not completely absolute, although many experts have proven a strong correlation between intentions and behavior, it turns out that in several studies there is also a weak relationship between the two. One of the reasons for this is the instability of intention. Therefore, future researchers are expected to find interventions that are able to maintain patient intentions so that these intentions can be converted into lasting behavior.

\section{ACKNOWLEDGMENTS}

The author is thankful for respondents for their valuable information and its awareness to participate in this research.

\section{CONFLICTS OF INTEREST}

The author declares that they have no conflict of interest

\section{REFERENCES}

Adiutama, N. M., Amin, M., \& Bakar, A. (2018a). Pengaruh Intervensi Edukasi Berbasis Theory Of Planned Behavior dalam Meningkatkan Kepatuhan Pasien Tuberkulosis. Universitas Airlangga.

Adiutama, N. M., Amin, M., \& Bakar, A. (2018b). An Evaluation of Medication Adherence in Tuberculosis Patients Based on Theory of Planned Behavior. Proceedings of the 9th International Nursing Conference, IX, 428-434. https://doi.org/10.5220/0008326204280434

Adiutama, N. M., \& Fauzi, A. K. (2020). Educational Intervention in Improving Tuberculosis Patient's Adherence Based on the Theory of Planned Behavior. The 2nd Strada International Conference on Health, 254-263. https://doi.org/10.30994/sich2.v2i1.14

Adiutama, N. M., Fauzi, A. K., \& Ellina, A. D. (2021). Intervensi Edukasi Berbasis Theory of Planned Behavior untuk Meningkatkan Kepatuhan Pengobatan, Nutrisi, dan Pencegahan Penularan pada 
Pasien Tuberkulosis. Jurnal Ilmiah Keperawatan (Scientific Journal of Nursing), 7(1).

Ajzen, I. (2005). Attitudes, Personality and Behavior (T. Manstead (ed.); 2nd ed.). Open University Press.

American Heart Association. (2015). Heart Disease and Stroke Statistics. American Heart Association

Caprio, F. Z., \& Sorond, F. A. (2018). Cerebrovascular Disease Primary and Secondary Stroke Prevention. Medical Clinics of NA, 1-14. https://doi.org/10.1016/j.mcna.2018.10.001

Farrag, M. A., Oraby, M. I., Ragab, O. A., Nasreldein, A., \& Shehata, G. A. (2017). Public Stroke Knowledge, Awareness, and Response to Acute Stroke: Multi-center study from 4 Egyptian Governorates. Journal of the Neurological Sciences. https://doi.org/10.1016/j.jns.2017.11.003

Folyovich, A., Biczó, D., \& Béres-molnár, K. A. (2018). Assessment of the Efficiency of Stroke Awareness Campaigns in Hungary. Journal of Stroke and Cerebrovascular Diseases. https://doi.org/10.1016/j.jstrokecerebrovasdis.2018.02.006

Hu, Y., Wang, C., Yan, X., \& Fu, H. (2017). Prediction of conscious awareness recovery after severe acute ischemic stroke. Journal of the Neurological Sciences. https://doi.org/10.1016/j.jns.2017.10.034

Jones, D., Adams, R. J., Simone, G. De, Ferguson, T. B., \& Flegal, K. M. (2010). Heart Disease and Stroke Statistics - 2010 Update . A Report From the American Heart Association. Journal of the American Heart Association, January 2009. https://doi.org/10.1161/CIRCULATIONAHA.108.191261

Kemenkes RI. (2018). Profile Kesehatan Indonesia Tahun 2018. In Ministry of Health Indonesia. https://doi.org/10.1002/qj

Kementerian Kesehatan. (2018). Hasil Utama Riskesdas 2018.

Miller, J., Modeste, N., Hopp, J., \& Jara, E. (2015). Applying The Theory of Planned Behavior to Understand Plate Waste of Elementry School Student. Proquest LLC.

Modi, R., Amico, K. R., Knudson, A., Westfall, A. O., Keruly, J., Crane, H. M., Quinlivan, E. B., Golin, C., Willig, J., Zinski, A., Moore, R., Napravnik, S., Bryan, L., Saag, M. S., \& Mugavero, M. J. (2018). Assessing effects of behavioral intervention on treatment outcomes among patients initiating HIV care: Rationale and design of iENGAGE intervention trial. Contemporary Clinical Trials, 69(February), 48-54. https://doi.org/10.1016/j.cct.2018.03.003

NSA. (2012). National Stroke Awareness Month Group Discussion Guide. National Stroke Assosiation.

Peleg, S., Vilchinsky, N., Fisher, W., Khaskia, A., \& Mosseri, M. (2017). Personality Makes a Difference: Attachment Orientation Moderates Theory of Planned Behavior Prediction of Cardiac Medication Adherence. Journal of Personality, 1-42. https://doi.org/10.1111/jopy.12294

Reese, P. P., Bloom, R. D., Trofe-clark, J., Mussell, A., Leidy, D., Levsky, S., Zhu, J., Yang, L., Wang, W., Troxel, A., Feldman, H. I., \& Volpp, K. (2016). Automated Reminders and Physician Notification to Promote Immunosuppression Adherence Among Kidney Transplant Recipients: A Randomized Trial. American Journal of Kidney Diseases. https://doi.org/10.1053/j.ajkd.2016.10.017

Venketasubramanian, N., Yoon, W., Pandian, J., \& Navarro, C. (2017). Stroke Epidemiology in South , East , and South-East Asia : A Review. Journal of Stroke, 19(3), 286-294.

Wilson, S. E., \& Ashcraft, S. (2018). Ischemic Stroke: Management by the Nurse Practitioner. The Journal for Nurse Practitioners. https://doi.org/10.1016/j.nurpra.2018.07.019 